\title{
LIBERALISMO Y LIBERTAD RELIGIOSA EN LA CONSTITUCIÓN DE 1869 (Acotaciones a un discurso)
}

CLARO J. FERNÁNDEZ-CARNICERO

Letrado de las Cortes Generales 


\section{SUMARIO}

I. El marCo histórico. 1. De la "Vicalvarada" a la "Gloriosa". 2. La Administración pública y el ordenamiento jurídico. 3. Administración de Justicia y Poder Judicial. 4. Los hombres de toga. II. Lo CONTENCIOSO-ADMINISTRATIVo. 1. Nacimiento y configuración. 2. La Revolución de 1868. 3. La Ley Orgánica del Poder Judicial. 3.1. Finalidad de la reforma. 3.2. Subsistencia de los contencioso-administrativo. Su naturaleza problemática. 3.3. Judicialización. 3.4. Consecuencias procesales. 3.4.1. Representación y defensa de los litigantes. 3.4.2. Incidente previo acerca de la admisibilidad de la demanda. 3.4.3. La actividad probatoria. 3.4.4. La resolución definitiva. 3.5. Conclusión. III. EL TRIBUNAL DE CUENTAS. 1. Características de la Ley Orgánica. 2. Delimitación jurisdiccional. IV. EPílogo: LA JUSTICIA CONSTITUCIONAL A LA VISTA. 


\title{
LIBERALISMO Y LIBERTAD RELIGIOSA EN LA CONSTITUCIÓN DE 1869 (Acotaciones a un discurso)
}

POR

\author{
CLARO J. FERNÁNDEZ-CARNICERO
}

Letrado de las Cortes Generales

Corría el 5 de mayo de 1869. Las Cortes Constituyentes celebraban sesión en el Palacio de la Carrera de San Jerónimo. José Echegaray, un joven diputado madrileño, ingeniero y profesor universitario, barba espesa y cabeza despejada, muy lejos de la plácida y dorada senectud que pintaría Sorolla, sube a la tribuna. Lo hace para defender la libertad religiosa plasmada en los artículos 20 y 21 del proyecto de nueva Constitución.

De su memoria no puede borrarse el recuerdo de las voces que, ya en los orígenes del liberalismo español del que es exponente la Constitución de 1812, denunciaron los límites de la libertad religiosa, al no superarse el régimen de cônfesionalidad del Estado.

Una de esas voces señeras fue la de Blanco White, cuando comenta desde Londres el alcance del artículo 12 de nuestro primer texto constitucional ${ }^{1}$, y denuncia la "intolerancia religiosa con que está ennegrecida la primera página de una Constitución que quiere defender los derechos de los hombres».

1 El Español, n. ${ }^{\circ} \mathrm{XXV}$, de 30 de mayo de 1812. 
Como principal razón de esa crítica, el insobornable sevillano arguye: "Si hubiera medios de forzar la creencia, podría disculpársele al celo el que los usase; pero si sólo pueden servir para hacer reservados e hipócritas, ¿por qué se han de establecer leyes que puedan degradar y abatir el alma de muchos españoles en cuanto hombres, sin mejorarles en cuanto religiosos?".

Echegaray se siente interpelado por esta transparencia moral del primer liberalismo $y$, al mismo tiempo, no ignora la posición condenatoria de la Iglesia, plasmada en la entonces reciente Encíclica de Pío IX, Quanta Cura (1864), que vendría a ser reforzada por el Syllabus. Ambos documentos consideraban pecaminosa la doctrina liberal.

Pero volvamos a la tribuna. La intervención que comienza es, como se denomina en la tradición parlamentaria inglesa, su «maiden speech" o primer discurso. Por ello, el orador hace gala de especial cortesia y prefiere la modestia al énfasis.

Quizás lo más acertado del enfoque inicial con que aborda la llamada "cuestión religiosa" es el reconocer su carácter "trascendental", por cuanto advierte que «afecta de tal modo a lo que hay de más intimo, a todo lo que hay de más profundo, a todo lo que hay de más esencial en la naturaleza humana". Esta declaración de la relevancia de la materia conduce al orador a fijar la premisa mayor de su discurso: "Todo sentimiento religioso es digno de respeto".

Tras esa introducción, Echegaray se centra en los aspectos jurídicos y políticos de la libertad religiosa. Ante todo, desde la perspectiva cercana de la Revolución de septiembre de 1868, nuestra tardía y efímera "Revolución Gloriosa», el diputado defiende la impronta liberal de la Constitución que se debate, cuyo espíritu pretende superar, tácita y prudentemente, el régimen concordatario de 1851.

El principal valor del nuevo marco político, es decir, su principio más singular, es el de la soberanía nacional. Ello determina, en palabras del interviniente, "que ha concluido el derecho antiguo, que ha concluido el derecho tradicional, que ha concluido el derecho históricon.

Con la más rotunda emoción, y para corroborar lo dicho de manera tan concluyente, Echegaray añade: «Sí, Señores Diputados, sobre el trágico puente de Alcolea ha tomado por fin nuestra España venganzas de Villalar".

Pero, además del dogma de la soberanía nacional, la Revolución de Septiembre, observa el orador, "ha proclamado los derechos indi- 
viduales como derechos superiores a la ley, como derechos superiores al legislador", en cuanto que emanan del mismo Dios, como ya había declarado Castelar en una sesión anterior.

"Antes teníamos reyes de derecho divino, y ahora", añade, "cada hombre es libre por derecho propio y por derecho divino". La libertad religiosa es uno de esos derechos. Porque cada templo o lugar de culto es, dice elevando el tono, "mi conciencia exteriorizada", es decir, la personalidad de quien libremente participa de una fe religiosa.

La libertad religiosa es, en suma, consecuencia inmediata de la libertad de pensamiento, que no puede encerrarse en fórmulas teológicas prefiguradas.

Por otra parte, Echegaray no contrapone, como haria el positivismo comtiano, el pensamiento científico a los sentimientos religiosos. Defiende la "perfecta armonía entre la ciencia y la religión", porque, a su juicio, «en el fondo de toda verdad científica ... hay un gran sentimiento religioso", porque la ciencia, en cuanto que aspira a alcanzar verdades objetivas y permanentes, es indisociable de lo trascendental, lo invariable y lo infinito. El orador recuerda que sobre lo transitorio, a lo que asocia el hecho revolucionario, está siempre la ley eterna.

Con ese espíritu de trascendencia, Echegaray afirma que se va hacia una democracia individualista, sin destruir por ello el hecho asociativo. Una vez más, aflora la tensión entre individuos y cuerpos intermedios, desencadenada con la Revolución Francesa.

Pero volvamos a sus palabras: «EI hombre va conquistando cada vez más su libertad, va siendo cada vez más dueño de sí mismo y de su destino, va adquiriendo mayores derechos, va emancipándose de toda fuerza exterior, sin que por ello se rompan las grandes atracciones morales», entre las que cuenta el influjo de la libertad religiosa. Por ello, "el hombre no es verdaderamente religioso, no se une verdaderamente con el infinito, sino cuando se une de manera espontánea, cuando se une por sí mismo". De ahi su derecho a equivocarse, su derecho al error, con la única limitación de respetar la libertad de los demás. Porque si el hombre no obra por su propio impulso, razona el orador, deja de ser hombre, es decir, responsable de sus actos y libre realizador de su propio destino.

Con ese nítido bagaje ideológico, Echegaray afirma, sin duda desde su perspectiva histórica, que «todo despotismo, toda tiranía, lo mismo el despotismo político que el despotismo democrático, no son 
otra cosa que verdaderos, profundos y radicales socialismos». Por eso, la unidad religiosa es para Echegaray un inmenso mal, porque un poder teocrático acaba convirtiendo esa unidad en arma de partido.

Frente a ese riesgo, la pluralidad de partidos, dentro de la cultura liberal, tiene el efecto positivo de conducir a la controversia y al debate. La discusión, dice con una arriesgada ingenuidad intelectual, sólo hace que nazca la duda en aquel que defiende el error; para aquel que defiende la verdad, la discusión la acrisola.

Ya en la coda final, el orador afirma que "en la libertad religiosa caben todas las conciencias, caben todos los pensamientos, caben todos los derechos".

Los taquígrafos del Salón de Plenos, fieles a su misión de registrar todo incidente surgido en la sesión, describen la reacción de la Cámara con estas palabras:

"Grandes y ruidosos aplausos; Diputados de todos los lados de la Cámara acuden a felicitar al orador".

José Echegaray, como los diestros del toreo, había tomado la alternativa, que sería el comienzo de una larga y brillante carrera politica, emparejada a una no menos exitosa carrera literaria.

Sin embargo, apagadas las luces de aquel proscenio, no podemos ignorar que en la Constitución aprobada el 1 de junio de ese año, su definitivo artículo 21 sería más una transacción que una ruptura con el régimen anterior. Basta recordar aquí su tenor, que es el siguiente:

"La Nación se obliga a mantener el culto y los ministros de la religión católica.

El ejercicio público o privado de cualquier otro culto queda garantizado a todos los extranjeros residentes en España, sin más limitación que las reglas universales de la moral y del derecho.

Si algunos españoles profesaren otra religión que la católica, es aplicable a los mismos todo lo dispuesto en el párrafo anterior».

Aunque, ante los hechos históricos, verba volant, los testimonios morales permanecen. 